\title{
Analysis of the forces exerted in flight by Aviator Cadets of the Brazilian Air Force
}

\section{Análise das forças exercidas em voo por Cadetes Aviadores da Força Aérea Brasileira}

\author{
Thiago Augusto Rochetti Bezerra1', Antônio Carlos Shimano², Fábio Angioluci Diniz Campos³ \\ $2^{\text {nd }}$ Lieutenant, Higher Education Teaching of the Brazilian Air Force. Estrada de Aguai s/n. Pirassununga, SP, Brasil. Post-Doctoral researcher at the Institute of \\ Physics of São Carlos/USP. Institute of Physics of São Carlos. São Carlos, SP, Brazil. <thiago rochetti@globomail.com>. \\ 2 Professor, School of Medicine of Ribeirão Preto, Department of Biomechanics, Medicine and Rehabilitation of the Locomotor System, School of Medicine of \\ Ribeirão Preto - USP., Ribeirão Preto, SP, Brasil. <ashimano@fmrp.usp.br>. \\ $2^{\text {nd }}$ Lieutenant, Higher Education Teaching of the Brazilian Air Force. Estrada de Aguai s/n. Pirassununga, SP, Brasil. Doctoral candidate in Human Movement Sciences, \\ Methodist University of Piracicaba. Pirassununga, SP, Brasil. <fabiocampos06@gmail.com> \\ Study conducted at the Air Force Academy, AFA, Pirassununga, SP, Brazil.
}

\begin{abstract}
Aim: To analyze the muscle strength of Aviator Cadets undergoing a training program in an EMB312/T-27 Aircraft Force Simulator prototype. Methods: The current study comprised of 56 Aviator Cadets from the Brazilian Air Force, divided into four groups $(\mathrm{N}=14): 2^{\text {nd }}$ Squadron, $4^{\text {th }}$ Squadron, Control Group and Female Aviator group. The protocols employed evaluated force measurements for isometric contraction time from the following maneuvers: nose-up, nose-down, rotation to the right, rotation to the left, and ejection force. Results: Statistical difference was observed for all groups, after training, for the nose-up maneuver. Only the Female Aviator group presented no significant statistical difference, after training, for nose-down maneuvers. The $2^{\text {nd }}$ Squadron and Female Aviator groups presented no statistical difference, after training, for the rotation movements to the left and right. The Female Aviator group presented no significant statistical difference for ejection force after training. Conclusion: A difference in force achievement was verified for the $4^{\text {th }}$ Squadron cadets in comparison to the other experimental groups. It was also possible to observe a significant difference in the isometric force of the male aviators in comparison to the females.
\end{abstract}

KEYWORDS: Force simulator; Aircraft T-27; Isometric force; Ejection; Brazilian Air Force

\section{RESUMO}

Objetivos: Analisar a força muscular de Cadetes Aviadores submetidos a um programa de treinamento utilizando o protótipo do Simulador de Forças da Aeronave EMB312/T-27. Métodos: Este estudo foi realizado com 56 Cadetes Aviadores da Força Aérea Brasileira dividido em quatro grupos $(\mathrm{N}=14)$, sendo: 2 ㅇ Esquadrão, 4⿳o Esquadrão, Controle do peso e Aviadoras. Os protocolos utilizados avaliaram as medidas de força em função do tempo de contração isométrica para os movimentos de Cabrar, Picar, Rotação Interna e Rotação Externa e da força de ejeção. Resultados: Foi observado que houve diferença estatística após treinamento para todos os grupos no movimento de Cabrar. Para o movimento de Picar somente o grupo Aviadoras não apresentou diferença estatística significante após treinamento. Para o movimento de Rotação externa e interna o $2^{2}$ Esquadrão e Aviadoras não apresentaram diferença estatística após treinamento. Para a força de ejeção o Grupo de Aviadoras não apresentou diferença estatística significante após treinamento. Conclusões: Foi verificada diferença na realização de força dos Cadetes $4^{\stackrel{0}{ }}$ esquadrão em relação aos demais grupos experimentais. Também se pode observar uma diferença significante da força isométrica de homens em relação às mulheres aviadoras.

PAlAVRAS-CHAVE: Simulador de forças; Aeronave T 27; Força isométrica; Ejeção; Força Aérea Brasileira

Pontifical Catholic University of Rio Grande do Sul Porto Alegre, RS, Brazil

Editor

Thaís Russomano

Microgravity Centre PUCRS, Brazil

Executive Editor

Rafael Reimann Baptista

Faculdade de Educação Física e Ciências do Desporto, PUCRS, Brazil

e-ISSN: 2179-703X
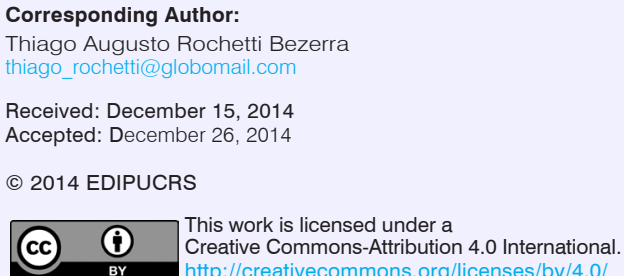


\section{Introduction}

Flight fatigue is defined as a state caused by air activity that deteriorates the psychophysiological condition of a crew, leading to a progressive reduction in their performance. ${ }^{5,6,12,17}$. Kanashiro (2005) proposes the approach of placing situations that generate flying fatigue into two groups: those originating from the air activity itself, designated as operational factors; and those arising from physiological, psychological and professional aspects, designated as individual factors.

The stress loads that individuals from this unusual profession are subjected to are extreme, and thus a lack of preparation or clear understanding of some physical symptoms can lead them to physical breakdown or even death ${ }^{7,8,29}$.

Technological developments have provided improvements in ergonomic design, computerized systems and air traffic control, resulting in a positive impact on flight safety. However, it is still of note worldwide that human factor remains prominent among the causes of air accidents ${ }^{10,11,26,32}$.

\subsection{Pilot Training in the Brazilian Air Force}

The Official Aviators Development Course (OADC) is certified by the Ministry of Education as a higher education course (Opinion document $\mathrm{n}^{\mathrm{o}}$ $672 / 80$ ). The course duration is 4 years. Throughout this period cadets receive general, specialist-technical and military instruction. Flight training in a T-25 aircraft is undertaken in the second academic year. In the fourth year cadets take-up flying in the $1^{\text {st }}$ Air Training Squadron (1 ${ }^{\text {st }}$ ATS), flying T-27 aircraft (Figure 1).

Figure 1. EMB 312 T-27 ${ }^{\circledR}$ Aircraft (Source: AFA)

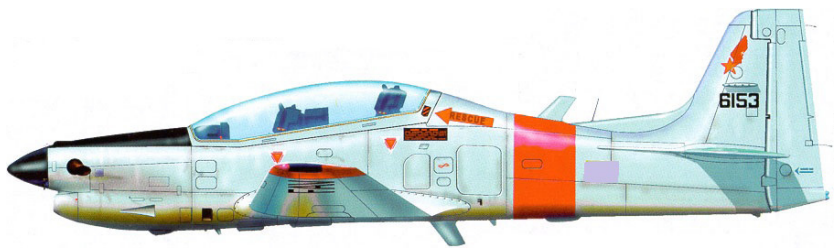

\subsection{Maneuvers}

Stick movements occur in all directions, but there are four basic maneuvers for aircraft motion: rotation to the left, nose-up, rotation to the right and nosedown.

\section{Objectives}

To analyze the muscle strength of Aviator Cadets of the Pirassununga Air Force Academy, SP, undergoing an ejection and aerobatics simulation training program using a T-27 aircraft Force Simulator (FS) prototype (SFA-EMB312/T-27)

\section{Materials and Methods}

Fifty-six cadets from both genders were divided into four groups: Group 1 comprised of $2^{\text {nd }}$ Squadron cadets; Group 2 of $4^{\text {th }}$ Squadron cadets; Group 3 of a Control Group of aviators, matched for weight; and Group 4 comprised of Female Aviators. The research project was submitted to and approved by the Research Ethics Committee of the Faculty of Medicine of Ribeirão Preto/USP - National Council for Research Ethics, which approved its implementation under Protocol $\mathrm{n}^{\circ}$ $340.178 / 2013$.

\subsection{Equipment and Instruments Used}

The equipment and instruments used in this project were:

1. EMB 312 T-27 "Tucano" aircraft FS prototype (SFA-EMB312/T27) developed at the Bioengineering Laboratory of the School of Medicine of Rio Preto - University of São Paulo, with support from the São Paulo Research Foundation ${ }^{4}$. Patent \# PI 0802590-8A2.

2. Electrical signal logger of the SFA-EMB312/ T27 prototype.

3. Ametek Mansfield and Green.Div ${ }^{\circledR}$ ejection dynamometer, adapted to the SFA-EMB312/ T27 prototype.

4. Ejection handle of the T-27 aircraft, adapted to the SFA-EMB312/T27 prototype.

\subsection{Force Simulator Prototype}

Figure 2 shows a frontal view of the FS prototype SFA-EMB312/T27.

Figure 2. Frontal view of the FS

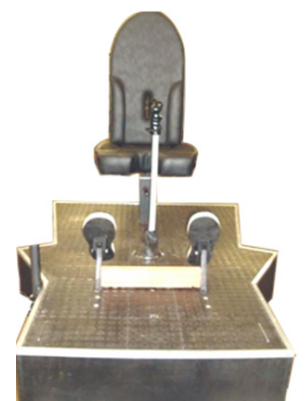


The SFA-EMB312/T27 prototype stick is connected at its lower end to 4 joints, one for each of the selected directions of the simulator. Steel springs with a load cell connected at their ends are used to calibrate the forces exerted on the stick. The load cells perform the measurement of forces.

Storage and processing of the forces data transmitted by each load cell, according to time, is carried out by an electrical signal logger, coupled to a computer. The electrical signal logger has software that converts signals acquired by the load cells into graphs of the force applied against time.

An Ametek Mansfield \& Green Division dynamometer, coupled to a T-27 aircraft ejection handle fixed to the base of the FS, was used to evaluate the ejection force.

\subsection{Technical Training}

Before carrying out training in the FS, cadets received specialized technical instruction from an experienced instructor regarding stick movement in the performance of aerobatic simulations and the correct form and positioning for ejection.

\subsection{Measurement of isometric force and ejection}

Measurements of the maximum time of isometric contraction were recorded for the following movements: (1) nose-up; (2) nose-down; (3) rotation to the right; and (4) rotation to the left. A 60 second maximum time was set for each move. This time was based on the duration of a real aerobatics maneuver. The time interval between moves was set at 30 seconds, which is equivalent to the time spent in real-life aircraft flight training ${ }^{22}$. Eight evaluations were conducted over a period of eight weeks. No training took place in the first four weeks during the Control Phase. Training began for the Training Phase from the fifth week onwards.

\subsection{Force (kgf) exerted in the Force Simulator}

Isometric force assessments were carried out in the FS calibrated for a $30 \mathrm{kgf}$ force. This is the maximum force applied while performing aerobatics in a $\mathrm{T}-27$ aircraft, subject to a gravitational force equal to $6 \mathrm{Gz}+$. Figure 3 presents a Female Aviator cadet carrying out the isometric force evaluation for a rotation to the left in the FS.
Figure 3. Female Aviator cadet undergoing a rotation to the left isometric force evaluation in the SFA-EMB312/T27

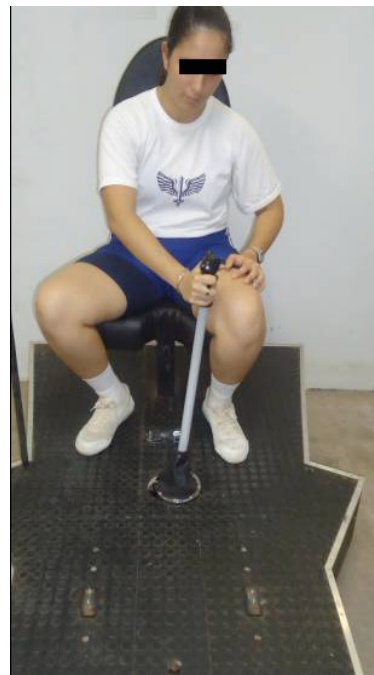

\subsection{Control Phase}

In the control phase, cadets underwent four evaluations of isometric force over a four week period using the stick and ejection handle in the FS. Evaluations were performed at the end of each week.

\subsection{Training Phase}

During the training phase, cadets carried out aerobatics simulations: four of isometric force by time and four of ejection force. Aerobatics simulations were performed by means of training conducted in the FS, always following the sequence: 1 - Looping, 2 - Barrel roll, 3 - Slow barrel roll and 4 - Returnemant. The 30 second interval between simulations is in agreement with the mean real-time interval between one aerobatics maneuver and another. The training protocol began with 4 repetitions of each aerobatics maneuver and, from the fourth week onwards, culminated in 16 repetitions. The number of repetitions was set in accordance with the training schedule during the flying phase. The plan was to adjust the training process to situations as near to reality as possible. The total training time ranged from $5 \mathrm{~min}$ to $20 \mathrm{~min}$ per training session. Three sessions per week were carried out during the training phase, with a total of 12 training sessions.

\subsection{Statistical Analysis}

Data obtained from the control and training phases were analyzed according to ANOVA one-way variance analysis $^{37,2}$. Results were found using the Bioestat 5.0 software ${ }^{2}$. The significance level was $\mathrm{p}<0.05$ for all performed tests ${ }^{2}$. 


\section{Results and Discussion}

A comparison of the mean times $( \pm \mathrm{SD})$ between the control and training phases for the nose-up maneuver showed a significant statistical difference for all four groups, as follows: $2^{\text {nd }}$ Squadron control phase $(25 \pm 2.16 \mathrm{~s})$, training phase $(33.5 \pm 2.08 \mathrm{~s})$ $(\mathrm{p}=0.0018) ; 4^{\text {th }}$ Squadron control phase $(34 \pm 2.58 \mathrm{~s})$, training phase $(48.5 \pm 5.44 \mathrm{~s})(\mathrm{p}=0.0035)$; Control Group control phase $(29 \pm 2.44 \mathrm{~s})$, training phase $(39.7 \pm 1.7 \mathrm{~s}) \quad(\mathrm{p}=0.0007)$; and Female Aviator group control phase $(21.5 \pm 2.12 \mathrm{~s})$, training phase $(26.5 \pm 2.38 \mathrm{~s})(\mathrm{p}=0.0203)$.

A comparison of the mean times $( \pm \mathrm{SD})$ between the control and training phases for the nose-down maneuver showed a significant statistical difference for three of the groups, as follows: $2^{\text {nd }}$ Squadron control phase $(24 \pm 1.41 \mathrm{~s})$, training phase $(27.75 \pm 2.21 \mathrm{~s})$ $(\mathrm{p}=0.0285) ; 4^{\text {th }}$ Squadron control phase $(32 \pm 2.94 \mathrm{~s})$, training phase $(37.25 \pm 2.06 \mathrm{~s})(\mathrm{p}=0.0261)$; Control Group control phase $(28.25 \pm 3.3 \mathrm{~s})$, training phase $(34.5 \pm 3.1 s) \quad(p=0.00323)$. However, results for the Female Aviator group control phase (23.5 $\pm 0.57 \mathrm{~s})$ and training phase $(26.75 \pm 2.63 \mathrm{~s})$ showed no statistical difference $(\mathrm{p}=0.0511)$.

A comparison of the mean times $( \pm \mathrm{SD})$ between the control and training phases for the rotation to the right maneuver showed a significant statistical difference for two of the groups, as follows: $4^{\text {th }}$ Squadron control phase $(25 \pm 6.68 \mathrm{~s})$, training phase $(38.45 \pm 3.96 \mathrm{~s}) \quad(\mathrm{p}=0.0135)$; Control Group control phase $(21.50 \pm 3.10 \mathrm{~s})$, training phase $(29.16 \pm 4.36 \mathrm{~s})$ $(p=0.028)$. On the other hand, no statistically significant difference was found between results for the $2^{\text {nd }}$ Squadron control phase $(21.75 \pm 2.75 \mathrm{~s})$, training phase $(25.87 \pm 4.51 \mathrm{~s})(\mathrm{p}=0.1682)$; and the Female Aviator group control phase $(18.75 \pm 1.50 \mathrm{~s})$, training phase $(213 \pm 1.71)(\mathrm{p}=0.0652)$.

A comparison of the mean times $( \pm \mathrm{SD})$ between the control and training phases for the rotation to the left maneuver showed a significant statistical difference for two of the groups, as follows: $4^{\text {th }}$ Squadron control phase $(20.75 \pm 3.86 \mathrm{~s})$, training phase $(31.5 \pm 3.1 \mathrm{~s})$ $(\mathrm{p}=0.0051)$; and Control Group control phase $(22 \pm 5.03 \mathrm{~s})$, training phase $(35.25 \pm 1.5 \mathrm{~s})(\mathrm{p}=0.0029)$. However, no statistically significant difference was found between results for the $2^{\text {nd }}$ Squadron control phase $(21.50 \pm 3 \mathrm{~s})$, training phase $(21.75 \pm 2.21 \mathrm{~s})$ $(p=0.8928)$; and the Female Aviator group control phase $(20 \pm 1.82 \mathrm{~s})$, training phase $(23.50 \pm 4.04)$ $(\mathrm{p}=0.1635)$.

Analyzing the time for each maneuver, results for the $2^{\text {nd }}$ squadron showed an increase between the control and training phase of $25.3 \%$ for the nose-up, $13.5 \%$ for the nose-down and $15.9 \%$ for the rotation to the right maneuvers, with only a $1.14 \%$ increase noted for rotation to the left.

The higher values recorded for the $4^{\text {th }}$ Squadron were $29.89 \%$ for the nose-up, $14.09 \%$ for the nosedown, $34.09 \%$ for rotation to the right and $34.12 \%$ for rotation to the left maneuvers.

The increased values recorded for the Control Group were $26.5 \%$ for the nose-up, $18.1 \%$ for nosedown, $26.2 \%$ for rotation to the right, and $37.5 \%$ for rotation to the left maneuvers.

An analysis of the time for each maneuver performed by the Female Aviator cadets showed recorded increases of $18.8 \%$ for the nose-up, $12.1 \%$ for the nose-down, $11.9 \%$ for rotation to the right and $14.8 \%$ for rotation to the left maneuvers.

Results of the aerobatics simulation force training presented positive results. The $4^{\text {th }}$ Squadron was seen to stand out in relation to the other groups. This may relate to the natural adaptation of the cadets over the four years of training. The difficulties demonstrated by both the $2^{\text {nd }}$ Squadron and Female Aviator groups can also be noted. These groups presented little improvement after training. The Control Group was formed of cadets with various years of training (2, 3 and 4 years). Despite this being an assorted group, it presented good results in response to the training program. However, it is true that all groups after training reached higher levels than those recorded during the control phase.

The results presented reinforce the idea that there is a significant difference between the muscle strength of male and female pilots. It suggests that squadrons including female aviators should have closer monitoring and specific training to ensure the female aviators reach values closer to those of the male aviator cadets.

Physical training for Brazilian Air Force pilots can help identify possible causes of pilot injury. According to statistics from the United States Air Force (USAF), 2013, the prevalence of the direct participation of inflight muscle fatigue in air accidents is in terms of $5 \%$. However, when signs and symptoms derived from this fatigue are considered, such as a lack of attention, mistaken perception and a deficient decision-making process, the index can be closer to 35\% (USAF, 2013). There is no statistical study on the prevalence of fatigue in-flight in the BAF.

The relevance of the statistical data justifies the interest in knowledge of the etiological factors of this clinical condition in the BAF. These concepts support other researches ${ }^{8,30}$, aiming to provide backing for the implementation of methods, protocols and standards for its prevention. 
The work in this specific field of aerospace medicine demonstrates the importance of research. Whilst there have been advances in the diagnosis and treatment of related diseases and a consequent increase in qualityof-life and activities performed by aviators ${ }^{12,13,16,28}$, it is worth highlighting that muscle fatigue can alter perception of the deficiency itself, meaning that by not being aware of their own state, the pilot may continue in their activity whilst suffering a deteriorated physical condition $^{5,18,30}$. There are very few studies related to these criteria in the BAF.

Kemppainen, Hämäläinen and Könönen (1998) demonstrated that intense physical exercise increased the pain threshold in fighter pilots suffering from episodes of "neck pain", as well as diminishing responses to discomfort.

According to Epperson, Burton and Bernauer (2010), the influence of physical activity, when related to tolerance of G-load acceleration, has been discussed by many authors over the years. It is certain that evidence exists in the scientific literature that a good state of physical conditioning allows pilots to more easily withstand the stresses inherent to the profession.

Gillingham (1988) states that anaerobic fitness is an important physiological component for increasing G-load tolerance and states that training with weights and counter-resistance results in significant increases, corroborated also by Epperson, Burton and Bernauer (1982).

Research performed by Whinnery and Parnell (1987) revealed there was a statistically significant increase in tolerance to G-load when associated with anaerobic fitness and recommend that its quantification needs to be better studied. A similar assumption can be found in Länsimies and Rauhala (1986).

Hartung et al., (1993) report that an increase in muscle strength may favor a better response to G-load tolerance. Nonetheless, the literature considers that anaerobic conditioning of strength is an important aspect in the development of fighter pilots, supporting the suggestions made in the current study.

Similarly, Gilligham (1988) shows in research performed by the USAF related to physical fitness and tolerance of $\mathrm{G}$ force that 12 weeks of strength training resulted in a significant increase $(\mathrm{p}<0.02)$ in $G$ tolerance. On the other hand, the control and aerobically trained groups presented no significant differences in such tolerance. The researcher explains this fact must be due to the stimuli arising from the $\mathrm{G}$ action, being short duration and high intensity isometric contractions and, thereby, predominantly involving anaerobic metabolism.
Epperson, Burton and Bernauer (2010) corroborate this, suggesting that strength training promotes a greater increase in tolerance to $\mathrm{G}$ forces, and concluding that it is fundamental for the fighter pilot.

Gilligham (1988), Epperson, Burton and Bernauer (1982), Whinnery and Parnell (1987), Länsimies and Rauhala (1986), and Dejurs (1992) may be correct when referring to associations between muscle strength and $G$ tolerance. It should be taken into account that energy recovery from anaerobic stimuli is derived from the aerobic system ${ }^{3}$ and flight fatigue comes not only from the actions of $\mathrm{G}$ force $\mathrm{e}^{23,26,29}$.

Hickman, Triebwasser and Lancaster (1980), and Joseph (1998) warn that subclinical diseases can manifest as sudden incapacitation and may lead to death due to high exposure to G-load, associated with other risk factors. Therefore, anaerobic conditioning of strength can contribute as a prophylactic measure against possible heart problems that might affect the fighter pilot, since, due to their profession, they have an increased potential for cardiac risk.

On the other hand, Moreira (1987) argues that aerobic conditioning should not be discounted, despite the evidence for strength work being notable.

More specifically when referring to fighter pilots, Jacobs (1987) mentions that strength training can improve tolerance to $\mathrm{Gz}+$ acceleration during simulated combat in a human centrifuge.

Besides being important within airlines and operational squadrons of the BAF, this monitoring most certainly cannot be overlooked during the selection and training processes of new pilots ${ }^{23}$.

It can be observed from the results related to ejection that the mean $( \pm S D)$ ejection forces showed a significant statistical difference between phases for three of the groups, as follows: $2^{\text {nd }}$ Squadron control phase $(53.25 \pm 8.49 \mathrm{kgf})$, training phase $(78.37 \pm 8.36 \mathrm{kgf}) \quad(\mathrm{p}=0.0061) ; 4^{\text {th }}$ Squadron control phase $(71.40 \pm 13.06 \mathrm{kgf})$, training phase $(103.50 \pm 5.44 \mathrm{kgf})(\mathrm{p}=0.0044)$; and Control Group control phase $(56.05 \pm 10.59 \mathrm{kgf})$, training phase $(88.47 \pm 8.44 \mathrm{kgf}) \quad(p=0.0036)$. However, results for the Female Aviator group showed no statistically significant difference between the control phase $(33.62 \pm 1.97 \mathrm{kgf})$ and training phase $(36.25 \pm 0.90 \mathrm{kgf})$ $(\mathrm{p}=0.0507)$.

In relation to the ejection force, the results demonstrate the mean figures achieved by the $4^{\text {th }}$ Squadron, $2^{\text {nd }}$ Squadron and Control Group are relevant in relation to the Female Aviator group.

According to Mylle (1998) military aviators should be physically prepared for heavier and more arduous tasks, and the level of muscle strength can be 
fundamental during emergency situations, such as in combat or during ejection.

In extreme conditions, the T-27 aircraft can reach values of up to $6 \mathrm{Gz}+$ before facing rupture of its structure. In such unfavorable conditions, the pilot must eject. Drawing a parallel between the required ejection force in kgf and the $\mathrm{Gz}+$ force, no group reached the $6 \mathrm{Gz}+$ maximum value. In these results, the Female Aviator group achieved values lower than $2 \mathrm{Gz}+$, which could indicate a low capacity to eject should such an occurrence ever occur.

The percentage results for ejection showed an important finding. The $2^{\text {nd }}$ Squadron, $4^{\text {th }}$ Squadron, and Control Group achieved improvements above 30\%, being 32\%, 31\% and 36\%, respectively. Conversely, the Female Aviator cadets made a slight improvement of $7.2 \%$ after training.

The current study identified a difference between men and women, with some studies also reporting the inequality between genders. Women present less muscle mass in comparison to men, reflecting lower availability of muscle energy in such a case (Fox, 2000). It is possible to draw a parallel with the effort expended in air combat maneuvers, usually lasting 2-3 minutes. The maximal aerobic power $\left(\mathrm{VO}_{2} \max \right)$ of women is also $15-25 \%$ lower than that of men, mainly due to factors linked to body size $\mathrm{e}^{36}$.

In 1992, a Presidential Commission in the United States conducted a study seeking to improve female conditioning in the army in order to help them reach the same fitness standards as their male counterparts. Only 3.4\% of women achieved the male mean standard, at a cost of doubling the rate for injuries to the lower extremities and having 4 times more fracture cases. From the anaerobic power: measurement of individual capability to produce power in a localized muscle area, independent of blood or oxygen supply, it was concluded that the women studied had $50 \%$ to $60 \%$ of the muscle strength in their upper torso in comparison to men, as well as only $70 \%$ to $75 \%$ of aerobic capacity ${ }^{30,35,36}$.

In relation to tolerance to the $\mathrm{Gz}+$ force, studies performed in human centrifuges have shown the negative influence of the gender factor. In general, women are smaller, pointing to a lower tolerance than men. A comparison of individuals of the same stature showed that women have about $15 \%$ lower tolerance ${ }^{30,36 \text {. }}$.

Another critical criterion for aircraft equipped with an ejection seat is the individual crew weight, which should be between $58.65 \mathrm{~kg}$ and $93.53 \mathrm{~kg}$ in order to ensure safety of operation ${ }^{22}$. Women have presented difficulty in meeting the lower limit for this measure.
An unprecedented study was initiated in 2013 involving all pilots and cadets of the BAF. This ongoing study aims to evaluate the anthropometric profile of the Brazilian pilot. A major problem for the BAF is due to the fact that aircraft components are not all produced in Brazil. The ejection seat of the T-27 aircraft has anthropometric standards set for American and British pilots. This difference can hamper ergonomics and the suitability of Brazilian pilots for the national aircraft. The aim of this study will be to fabricate aircraft over the coming years that are appropriate for national anthropometric measurements.

Studies of the American Air Force (2005) have shown that the combination of physical strength and inadequate ergonomics results in a substantial percentage of women falling below the required criteria for operating the controls of fighter aircraft. Among the factors analyzed, the most restrictive was the ergonomic unsuitability of much of the female population for the cockpits and ejection seats of aircraft, as well as the flight equipment, since these were specified to meet the anthropometric standards of the male population.

Positive actions taken by the BAF, such as the acquisition of flight suits and equipment adapted to female anthropometric measurements, clinical and psychological monitoring, and the adoption of personalized fitness programs, will facilitate this integration.

\section{Conclusion}

Through this research it was possible to analyze and compare the muscle strength of Aviator Cadets in a Force Simulator prototype, measuring isometric force by time, and ejection force. The FS was able to train and evaluate the cadet in an aerobatics simulation program. A difference in strength was found when comparing the $4^{\text {th }}$ Squadron with the other groups, indicating there may be an adaptation of the aviator over the course of training. The Female Aviator group undertaking this experiment presented lower results than those of the men. Studies involving a larger number of participants and longer evaluation period should be performed to obtain more conclusive data on muscle strength in aviator cadets.

\section{References}

1. AFA. Academia da Força Aérea. Setor de Comunicação Social. Pirassununga; 2012.

2. Ayres MM, Ayres Jr DL, Santos AS BioEstat 5.0: aplicações estatísticas nas áreas das ciências biológicas e médicas: 1-364. Belém: Sociedade Civil Mamirauá; 2007. 
3. Astrand PO, Rodahl K. Tratado de fisiologia do exercício. Rio de Janeiro: Guanabara; 1987.

4. Bezerra THR. Projeto e desenvolvimento de simulador de forças da aeronave T-27 Tucano. 2008. 89f. [Dissertation Master Degree]. Department of Orthopedics, Traumatology and Reabilitation of the Musculoskeletal System. University of São Paulo, Ribeirão Preto-SP, 2008.

5. Caldwell JA. Fatigue in the aviation environment: overview of the causes and effects as well as recommended countermeasures. Aviation, Space and Environmental Medicine (Alexandria) 1997; 68(3):931-7.

6. Dejurs VA. High sustained $+\mathrm{Gz}$ acceleration: physiological adaptation to high- $G$ tolerance. Physiology Research Section, Air Force Research Laboratory, Brooks Air Force Base. Journal of Gravitation Physiology 1992; 5(1):51-5.

7. Epperson WL, Burton RR, Bernauer EM. The influence of differential physical conditioning regimens on simulated aerial combat maneuvering tolerance. Aviation, Space and Environmental Medicine 2010; 53(11):1091-7.

8. Gander PH, Rosekind MR, Gregory KB. Flight crew fatigue VI: a synthesis. Aviation, Space and Environmental Medicine (Alexandria) 2008; 69(9):B49-60. Suppl.

9. Gillingham KK. High-G stress and orientational stress: physiologic effects of aerial maneuvering. Aviation, Space and Environmental Medicine 1988; 59(11):A10-20. Suppl.

10. Hartung GH et al. Predictio of maximal oxygen uptake from submaximal exercise testing in aerobically fit and nonfit men. Aviation, Space and Environmental Medicine 1993; 64(5):735-40.

11. Hawkins FH. Human factors in flight. $2^{\text {nd }}$ ed. Vermont: Ashgate; 1993.

12. Hewson DJ, Mcnair PJ, Marshall RN. Aircraft control force and EMG activity in a $\mathrm{UH}-1 \mathrm{H}$ iroquois helicopter during routine maneuvers. Aviation, Space and Environmental Medicine 2000; 71(5):470-5.

13. Hickman JR, Triebwasser JH, Lancaster MC. Physical standards for high-performance fighter aircraft pilots. Aviation, Space and Environmental Medicine 1980; 51(9): 1052-6.

14. Hoffman ML et al. Effects of resistence training on lumbar extension strength. The American Journal of Sports Medicine 1999; 17(4):624-9.

15. Humphrey RP et al. The spine and fitness for flight. Physiopathology and pathology of spinal injuries in aerospace medicine. Neuilly-sur-Seine: AGARD; 1978. p. 221-63.

16. Joseph J, Albano MD, Stanford MD. Prevention of minor neck injuries in F-16 pilots. Aviation, Space and Environmental Medicine 1998; 69(3):1193-9.

17. Kanashiro RG. Fadiga de voo. In: Temporal W. (Org.). Medicina aeroespacial. Rio de Janeiro: Luzes; 2005. p. 335-42.

18. Kemppainen P, Hämäläinen $O$, Könönen M. Different effects of physical exercise on cold pain sensitivy in fighter pilots with and without the history of acute in-flight neck pain attacks. Med Sci Sports Exerc 1998; 30(4):577-82.

19. Knundson, R.; Mcmillan, D.; Doucette, D. A comparative study of G-induced neck injury in pilots of the F/A-18, A-7 and A-7. Aviation, Space and Environmental Medicine $1988 ; 59(5): 758-60$

20. Länsimies EA, Rauhala E. Orthostatic tolerance and aerobic capacity. Aviation, Space and Environmental Medicine 1986; $57(3): 1158-64$
21. Martin Backer. Manual do assento ejetor. MK8LC. Londres; 2012.

22. Manual E.M.B 312 T 27. Normas técnicas da aeronave Embraer T-27. Rio de Janeiro: Força Aérea Brasileira; 1984.

23. Moreira SB. O comportamento do ritmo cardíaco nos voos de caça. 2005. 78f. [Tese Livre Docência]. Universidade Gama Filho, Rio de Janeiro, 1987.

24. Mylle G, Moens G, De Raeve H, Viaene B, Lahaye D. Body mass index, industrial accidents and sick leave: further evidence of an association. Arch Public Health 1998; $56(56): 81-91$.

25. Naval Air Wafare Center Aircraft Division. Patuxent River, Maryland 20670-1906, USA Dynamic strength capabilities of small-stature females to eject and support added head weight. Shender BS, Heffner PL. Aviation, Space and Environmental Medicine 2001 Feb; 2(2):100-9.

26. Raymond RB. Cabina ir quality: overview. Aviation, Space and Environmental Medicine (Alexandria) 2002; 73(3): 211-5.

27. Robbins SD. Characterizing the effetcts of airborne vibration on human body vibration response. Aviation, Space and Environmental Medicine 2005; 73(8):36-45.

28. Rosenthal L et al. Enforced 24 hours recovery following sleep deprivation. Aviation, Space and Environmental Medicine 2011; 14(5):448-53.

29. Silva Junior I. Análise dos manuais de aprendizagem de voo. Rio de Janeiro: Universidade da Força Aérea, Escola de Comando e Estado Maior; 2006.

30. Strauss S. Pilot fatigue. Houston: NASA/Johnson Space Center; 2005.

31. Super tucano na FAB, por que a Força Aérea escolheu o Embraer ALX. Revue Avião (Rio de Janeiro) 2007; 3(2): 86-91.

32. Temporal RCM. Medicina aeroespacial: história e evolução. Rio de Janeiro: Centro de Medicina Aeroespacial da Força Aérea Brasileira, São José dos Campos-SP; 2005.

33. United States Air Force (USAF). Careers in aerospace medicine. Disponível em: <http://www.airforce.com $>$. Acesso em: 27 abr. 2013.

34. Velasco Díaz, C. et. al. Medicina aeronáutica: actuaciones y limitaciones humans. Madri: Paraninfo, 1995.

35. Whinnery JE, Parnell MJ. The effects of long-term aerobic conditioning on $+\mathrm{Gz}$ tolerance. Aviation, Space and Environmental Medicine 1987; 58(8):199-204.

36. Wilson AR. Causes and effects as well as recommended. Aviation Space and Environmental Medicine 2005; 68(6): 132-45.

37. Zar JH. Biostatistical analysis: 1-662 + app. New Jersey City: Prentice Hall, Englewood Cliffs; 1999.

38. 1ํ Esquadrão De Instrução Aérea. Ministério da Defesa. Manual de Instruções da Aviação. Pirassununga, SP: Comando da Aeronáutica; 2012.

39. 2ํ Esquadrão de Instrução Aérea. Ministério da Defesa. Manual de Instruções da Aviação. Pirassununga, SP: Comando da Aeronáutica; 2012.

Correspondence address:

Thiago Augusto Rochetti Bezerra

Av. José Antunes de Lisboa, 840, apto 13

13613-130 Leme, SP, Brasil

Tel.: (019) 9976-78229

<thiagorochetti@globomail.com> 